\title{
Historical vignette of Cajal's work "Degeneration and regeneration of the nervous system" with a reflection of the author
}

\author{
R.D. Lobato
}

Servicio de Neurocirugía, Hospital "12 de Octubre". Facultad de Medicina, Universidad Complutense, Madrid, Spain

KEY WORDS: Ramón y Cajal. Nervous system. Brain. Spinal cord. Somatic and sympathetic ganglia. Peripheral nerve. Neural degeneration. Neural regeneration.

Nota histórica sobre la obra de Cajal, "Degeneración y Regeneración del Sistema Nervioso", con una reflexión del autor

PALABRAS CLAVE: Ramón y Cajal. Sistema nervioso. Cerebro. Medula espinal. Ganglio raquídeo. Ganglio simpático. Nervio periférico. Degeneración nerviosa. Regeneración nerviosa.

\section{Introduction}

In 2006 many scientists and institutions commemorated the award of the Nobel Prize to Santiago Ramón y Cajal, the neuroscientist who analyzed the microanatomical structure of the nervous system of the vertebrates in such an extensive manner that it becomes difficult to understand how a single man could do so much high quality work ${ }^{7}$. As he did with the study of the normal nervous system ${ }^{8}$, Cajal used a throughout and systematic approach to investigate the degenerative and regenerative changes caused by different types of mechanical injuries inflicted to every component of the nervous system, coming from the brain and the optic nerve to the sensory and sympathetic ganglia, the spinal cord and its roots and the peripheral nerves. In the following sketch I resume the findings published in the book entitled "Degeneration and Regeneration of the Nervous System"10.

Sir Michael Foster in his history of Physiology Michael Foster stated "It is one of the lessons of history of science that each age steps on the shoulders of the ages which have gone before. The value of each age is not in its own but is in part, in large part, a debt to its forerunners".

Cajal performed most of the studies on this particular subject between 1905 and 1911, after he had made his major contributions to neurobiology (Table 1). These stu-

Recibido: 8-10-07. Aceptado: 12-12-07 dies were first published in part in Spanish (mostly in the journal "Trabajos del Laboratorio de Investigaciones Biológicas"), and in German ("Studien über Nerven Regeneration", Leipzig, 1908). The complete version of the work was published in Spanish in 1913 and then translated into English in 1928 ("Degeneration and Regeneration of the Nervous System", Oxford University Press; Facsimile of 1928 edition, Harper Press, New York, 1969). This marvellous book, which must be read by every worker in the field of nervous regeneration, perhaps the most attracting issue in neurosciences nowadays, includes two major sections, one devoted to the peripheral nervous system (Volume I), and the other dealing with the nerve centres (Volume II). Cajal included some experiments and observations made by his pupils and coworkers (Tello, Leoz, Arcuate, de Castro, Lorente de Nó, Achúcarro), as well as extensive comments on the work of nearly eighty contemporary neurobiologists (His, Kölliker, Retzius, von Lenhossék, Bethe, Harrison, Marinesco, Minea, Nageotte, Lugaro, Perroncito, Levi, Sala Bielchowski, Dustin, Forssman, Vulpian, Bünger).

The origin of Cajal's interest in nervous regeneration is worth some comment. At the beginning of the $\mathrm{XX}^{\text {th }}$ century the reticularists resumed the attack against the neuron theory. The partisans of the polygenist or catenary theory (Ballance, Bünger, Apathy and others with Bethe as a leader) argued that the nerve fibres reinnervating the peripheral stump of transected nerves were produced by

Table 1

Cajal's major discoveries

1.Individual cells are the basic units of the nervous system

2. The synapse

3. Polarization of nerve cells

4. The cone of growth and its function

5. The cell organization of the central and peripheral nervous system of different animal species

* Waldeyer and Sherrington put the names to the neuron and the synapse, respectively 

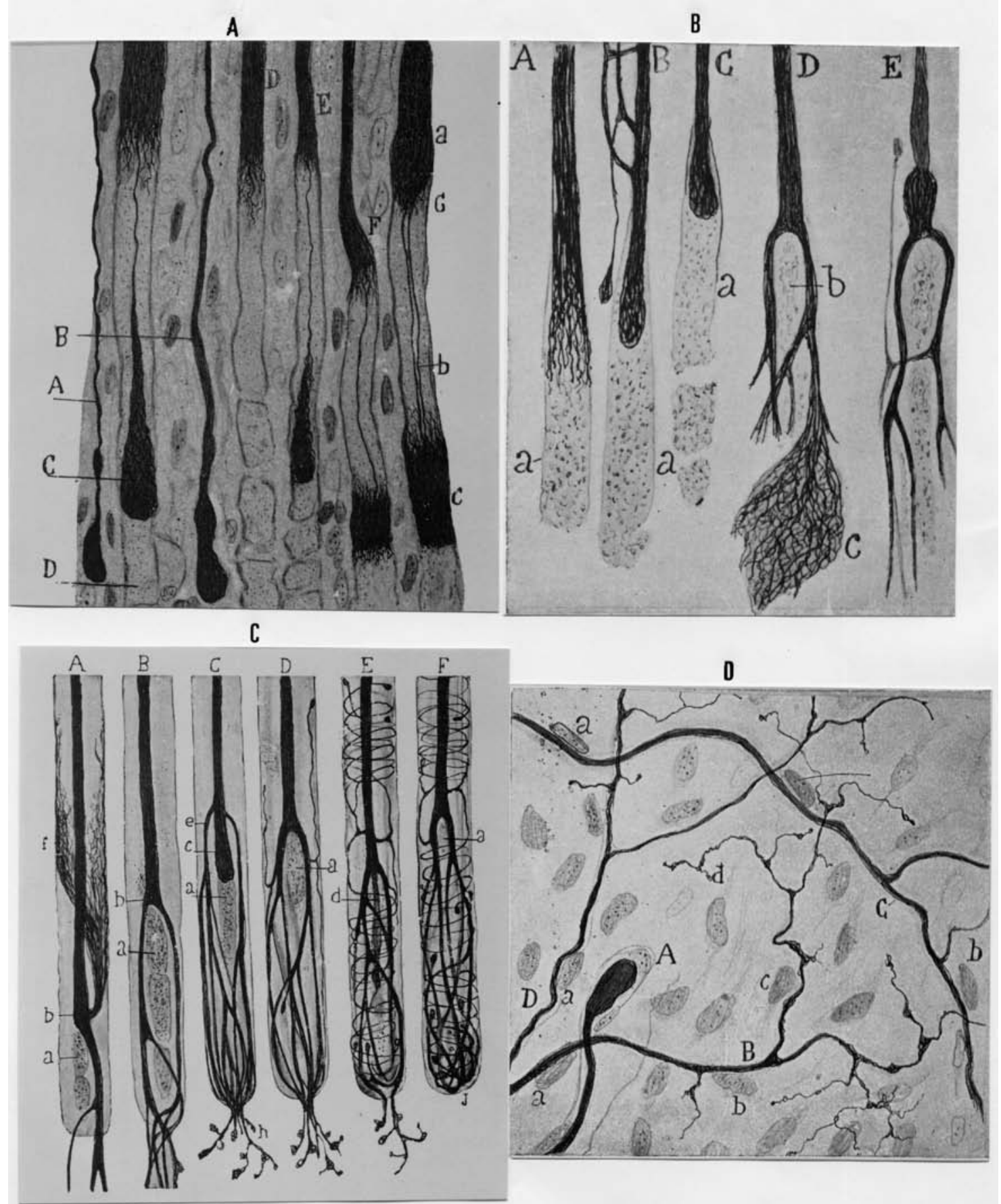

Figure 1. A. Piece of the peripheral stump of the sciatic nerve of a cat 2 days after section showing the agonal reactions and the general breaking up of the nerve fibres; the brushes of neurofibrils, the persistent axial neurofibrils and the terminal intumescences of hypertrophied neurofibrils destined to disappear. B. Central stump of the sciatic nerve of a cat 50 hours after nerve section. $B, C=$ axons whose ends are in the form of bulbs immersed in the disintegrated segment. $D, E=$ axons from whose terminal bulbs arise newly formed fibres. $C$. Schematic drawing of the form of the nerve branches in medullated fibres 3,5 days after nerve section; there are axons that give rise to ascending and descending branches, others emitting terminal branches and others showing intratubal collaterals. $E, F=$ helicoidal and sterile apparatus of Perroncito. D. Portion of the cicatricial nerve segment displaying fibres that are very much ramified. A large axon terminating in a club. $B=$ fibre in the state of division by amoeboidism. 
mesodermic cells and not by sprouting of the axons of the central stump. Cajal, together with His, Forel, Stroebe and others, supported the monogenist, or continuity theory, according to which the newly formed fibres are only the prolongation by way of budding and growth of the nervous tubes of the central stump. Cajal, who started the studies on nervous regeneration with the main goal of refuting the polygenist theory stated in his memories: "Because of the sweeping of the error of reticularism I was compelled to make a halt in my way and go down to the arena with sorrow for wasting perhaps two or three years in anatomopathological investigations whose product could not be other than to prove a truth which had been demonstrated several years before by Waller, Ranvier, Stroebe and ourselves" ... "at the end of the campaign I felt, however, the joy to see that I had no lost the time". With respect to the polygenist vs monogenist controversy Cajal stated: "It is really remarkable that Waller, who was essentially a physiologist and who lived at a time when histological technique was so defective, was able to formulate the true solution of the problem. Paradoxical as it may appear it is certain that in this problem error is modern while truth is ancient". However, because of technical limitations Waller believed "that the cell of origin or trophic centre of the severed fibre remained perfectly normal, and that all the histological elements of the distal stump disappeared". Cajal by using the method of impregnation with silver, which allowed him to follow the nerve fibres through relatively thick sections of tissue, analysed the changes occurring in the distal and proximal stump of transected peripheral nerves leading to the definitive refutation of the catenary theory.

In the first chapters of volume I Cajal described in detail the phases of the wallerian degeneration of the peripheral stump from the premonitory fragmentation of the axon and the granular disintegration of the neurofibrils to the final resorption of the axon (Fig.1A). Then he analysed the time course of the degenerative and regenerative changes occurring in the central stump (Fig. 1B, C). Apart from the fibres in process of degeneration, he observed others emitting newly formed collaterals and others ending in clubs of growth able to penetrate into the region of the scar (Fig. 1D). Cajal stated: "In contrast to the clubs and masses lacking a generative capacity, there are others which are active, capable of sprouting, and to which we have given the name of bud or club of growth because their analogy to the cone of growth of embryonic axons. This structure, which enjoys autonomy, possesses great softness and plasticity and is extremely sensitive to mechanical and chemical variations of its surroundings, creates exploratory sprouts and orients them suitably in the space... The nerve sprouts as though pushed by an energetic and continuous impulse launch out into the scar where they try to open a way. Sometimes the club which acts as a battering ram against the obstacles hypertrophies... On the fourth day, when the scars is almost formed, the axons travel throughout with relative ease and speed... The cones of growth show predilection for the weak passages... Once a first gap is made in the nerve border all the neighbouring fibres take advantage of it... The fibres divide before obstacles (capillaries, fat cells, etc.) and the new fibres pass round them... Where there are insuperable obstacles to reunion, the peripheral segment shows absolutely no regeneration even months after the operation, in contrast to the opinion of Bethe and other polygenists. The cells of Schwann segregate stimulating substances which are able to attract and direct the young nerve fibres to the motor and sensory nerve endings".

In 1892 Cajal had formulated the hypothesis of chemotactism, that is of amoeboidism of young axons brought about by an orienting stimulus from attracting or neurotropic substances. In 1906 he analysed the behaviour of nerve sprouts in the presence of embryonic connective tissue, exudates and different organic tissues (blood, muscle, fat, etc.). He stated: "The young connective tissue is of all the organic tissues, except the nerve tissue itself, that which is most favourable to nutrition and growth of the sprouts... the muscular tissue is also very favourable to the growth, while blood and adipose tissue are retarding obstacles".

In relation to the innervation of the peripheral stump, Cajal determined the speed of growth under different conditions and the effects of distinct types of lesion on the time of reunion (section, hemisection, crushing, compression, ligature, cold, heat) (Fig. 2A-C). He also performed multiple experiments on nerve grafting (union of two central stumps, inversion of a sequestered piece of nerve, homoand heterotransplantation of nerves), and used degenerated or dead grafts to demonstrate that the process of attraction and penetration of the new fibres into the peripheral stump is closely related to the vitality of the cells of Schwann (Fig. 2D). Finally, Cajal also studied the reinnervation of the nerve terminals: "After a journey through the peripheral stump the nerve sprouts attack the small terminal sensory and motor nerves and occurs the reunion of the muscle fibres and the sensory structures... Many months after nerve section all that is usefull remains, and all that is superfluous and aberrant undergoes degeneration and resorption".

At the end of Volume I, Cajal summarizes the general theoretical interpretation of the phenomena of nervous regeneration, and formulates the laws governing the process (law of continuous growth, law of growth in a straight line, and law of atrophy through disuse). The volume comes to the end with an excellent analysis of the different explanatory theories of normal and pathological neurogenesis at that time (theory of preestablished paths, mechanical theory, chain or catenary theory of polygenist and theory of neurotropism).

In the first chapters of Volume II, Cajal analysed the 


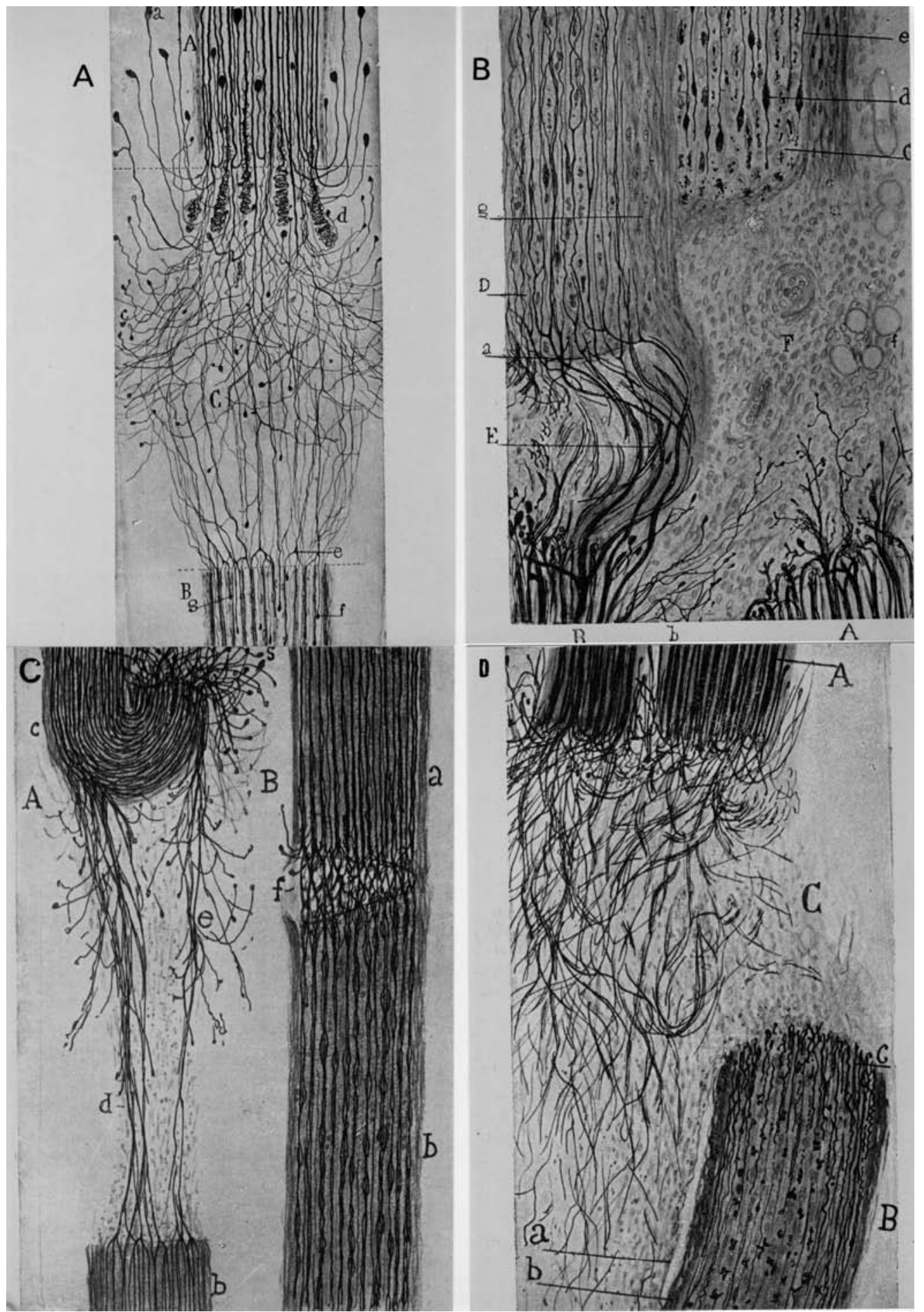

Figure 2. A. Scheme of the general disposition of the fibres in the central stump (A), scar (C) and peripheral stump of a sectioned nerve following reinnervation. B. The influence of the distance between the central and peripheral stump on the reinnervation is shown; such a distance has been increased on the right side by removing a small piece of the peripheral stump; reinnervation is rapid on the left but on the right side the sprouts are lost in the scar. $C$. The influence of the folding back of the proximal stump on reinnervation is shown in A. In B the easy reinnervation following nerve hemisection can be seen. D. Graft (B) of a nerve killed by chloroform into the wound of a sciatic nerve; the dead cells of Schwann are incapable of segregating attracting substances and the sprouts arising from the central stump (A) are lost in the scar. 


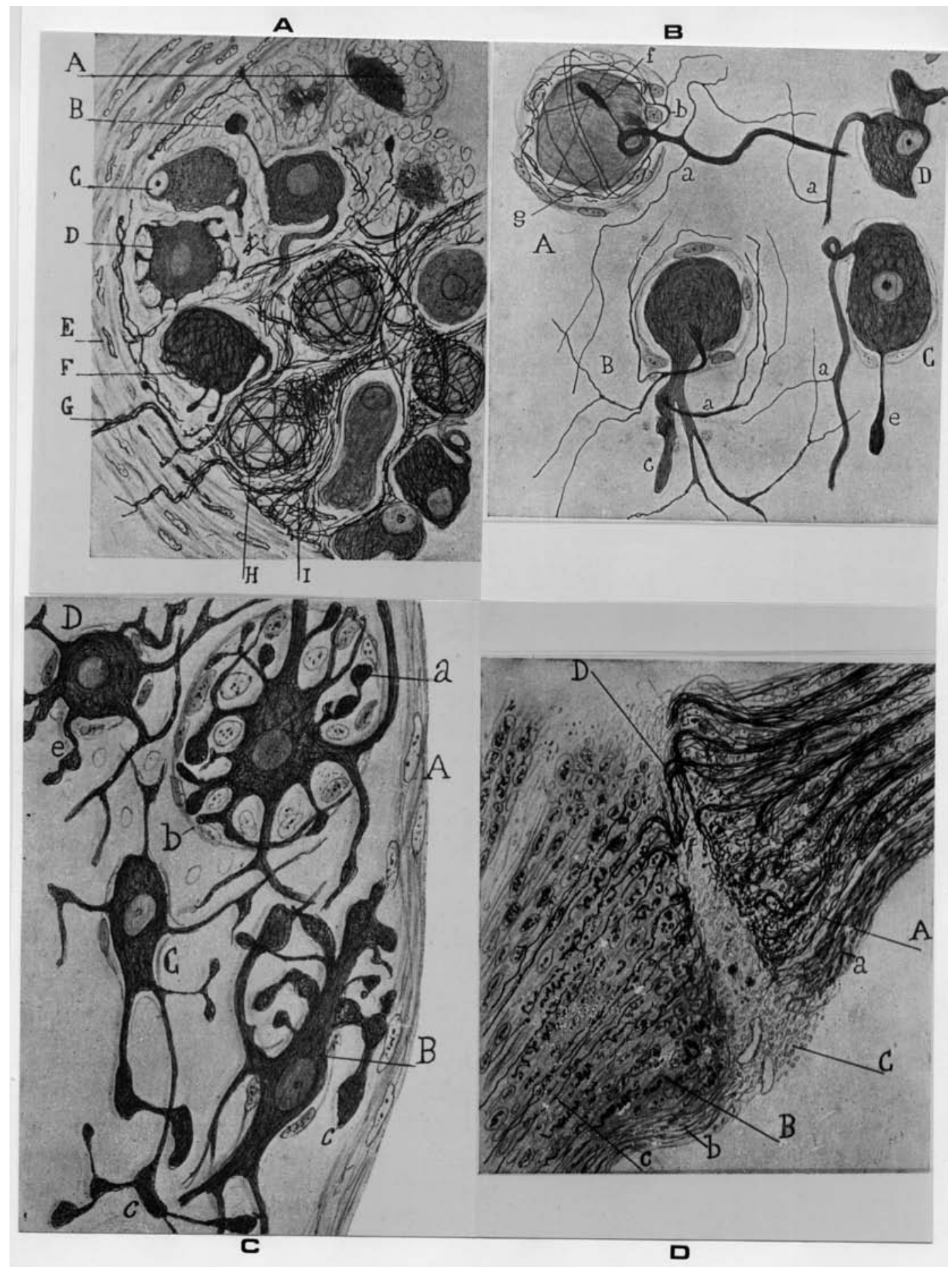

Figure 3. A. Piece of a sensory ganglion of a young cat killed 5 days after extirpation of the sciatic nerve; apart from the dying, necrosed cells, there are others from which arise appendices ending in balls $(B)$ and others showing pericellular sprouts. $G=$ newly formed fibres which cross the capsule of the ganglion. B. Types of ganglionic sprouting taken from the ganglion of a cat killed 5 days after extirpation of the sciatic nerve; cells with pericellular plexus and branching arising either from the axon or from the cell soma. C. Cells from a sympathetic ganglion grafted in a young cat killed 7 days after the operation showing subcapsular excrescences and newly formed appendices ending in clubs or forming tuberosities and terminal thickenings. D. Graft of a sciatic nerve on the retinal stump of the optic nerve of a rabbit; numerous sprouts arising from the optic nerve (A) pass the intercalary scar $(C)$ and reach the transplanted sciatic nerve (B), travelling along it. 
degeneration and regeneration of the sensory and sympathetic ganglia in different pathological (aging, trauma, infection, etc.), and experimental (section of peripheral nerve, roots, transplantation) situations. Following traumatic injuries the sensory ganglia show centrifugal degeneration: apart from de dying cells there are others which survive showing unequivocal reactive metamorphoses (Fig. $3 \mathrm{~A}, \mathrm{~B})$. The regenerative attempts of surviving cells consist of pericellular branching resulting in the formation of nests and the emission of newly formed fibres able to cross the capsule of the ganglion. In experiments with transplanted sympathetic ganglia (in vivo and in vitro) Cajal also observed the indubitable survival of many cells emitting sprouts in the form of thick, varicose, intracapsular expansions (Fig. 3C).

Cajal together with Tello, Leoz and Arcuate analysed the degeneration and regeneration of the optic nerve and retina, and assessed the possibility to simulate neurocladism by interposing sciatic nerve grafts between the retinal (central), and the peripheral segment of transacted optic nerves. Normally, the sprouts arising from the retinal stump are unable to cross the first third of the scar, but following nerve grafting they are able to penetrate the graft and travel along it for long distances (Fig. 3D). In the following chapters Cajal described in detail the degenerative and regenerative phenomena occurring in the wounded spinal cord at the level of the white matter tracts, the grey matter neurons and the spinal roots. The wallerian degeneration of the ascending and descending axons separated from their cell bodies is similar to the process occurring in the peripheral nerve but the engulfing or digestive function of the cells of Schwann is here taken over by the elements of the glia. Cajal stated: "Pathologist consider it an unimpeachable dogma that there is no regeneration of the central paths, but we and others have demonstrated beyond doubt that there is a production of new fibres and clubs of growth in the spinal cord following different types of insults". Cajal evidenced the regenerative attempts of the white matter fibres (arborisation, emission of thickened collaterals destined to be transformed in terminal fibres), of the grey matter neurons (emission of sprouts able to penetrate the region of the scar), and the regenerative phenomena at the level of entrance and exit of the spinal roots (Fig. 4A-D).

When studying the traumatic degeneration of the cerebellum, Cajal observed that the degenerative phenomena are similar to those seen in the spinal cord except for the fact that axonic resorption is arrested at the level of the emission of the first collateral (Fig. 5A). Following disappearance of the extracollateral part of the wounded axon, the Purkinje cells are transformed into neurons with a short axon. In relation to this observation, Cajal stated: "I have demonstrated for the first time the capacity of neurons to remain alive after the extirpation of their axon on the condition that the mutilation has been effected beyond the region of emergence of the recurrent collaterals and that the nervous impulse received by the dendrites can consequently be deflected toward the congenerous nerve cells". Cajal designed a scheme to show the possible paths of current an the short-axon Purkinje cells (Fig. 5B): "Perhaps, the impulse arising in these neurons falls back upon cells with a normal axon thus increasing the energy of the efferent current". Cajal speculated on the possibility that the same form of dynamic compensation could occur in the traumatized cerebral cortex which also contains pyramidal cells with a short axon produced in the same way (Fig. 5C).

In the last section of the book, Cajal described the degenerative and regenerative processes of the cerebrum exposed to traumatic injuries. He noted the exquisite susceptibility of the cerebral fibres and cells to the mechanical effects of trauma: "The least commotion or compression brings about the almost instantaneous death of the nervous protoplasm and the peculiar phenomenon of preservation, that is necrosis associated with the most perfect morphological integrity" (Fig. 5D). In relation to the impossibility of the nerve centres for regeneration Cajal stated: "Although in the cerebellum and cerebrum the ability to restore the interrupted paths and innervate the cicatricial tissue is always lacking, we do not hold the view, however, that the interrupted central axons have absolutely no neurocladic activity....In man affected by various nervous diseases and in young animals exposed to traumatisms we observed regenerative phenomena (Fig. 5E-G). It is true that such reactions are ephemeral, aborted and purposeless, but although unspecific they merit careful study. No matter what their significance, these productions have a positive biological interest".

Cajal believed that the tendency to restoration of nerve paths in the cerebrum is frustrated by two negative conditions: the lack of substances able to sustain and invigorate the indolent growth of the sprouts, and the absence of catalytic agents capable of attracting and directing the axonic current to its destination. "From this it may be inferred that if experimental neurology is some day to supply artificially the deficiencies in question it must accomplish these two objects: First, it must give to the sprouts by means of adequate alimentation a vigorous capacity for growth, and second, place in front of the disoriented nerve cones and in the thickness of white matter tracks, specific orienting substances". Cajal believed this last experimental condition almost impossible to satisfy, but Tello and himself tried to demonstrate that the first of these conditions was relatively practicable. For this purpose they implanted into the cerebral wounds of adult rabbits grafts of sciatic nerve and observed the attracting, stimulating effect of the newly formed fibres which penetrate into the graft (Fig. 5G). In spite of the success of these experiments Cajal believed that 


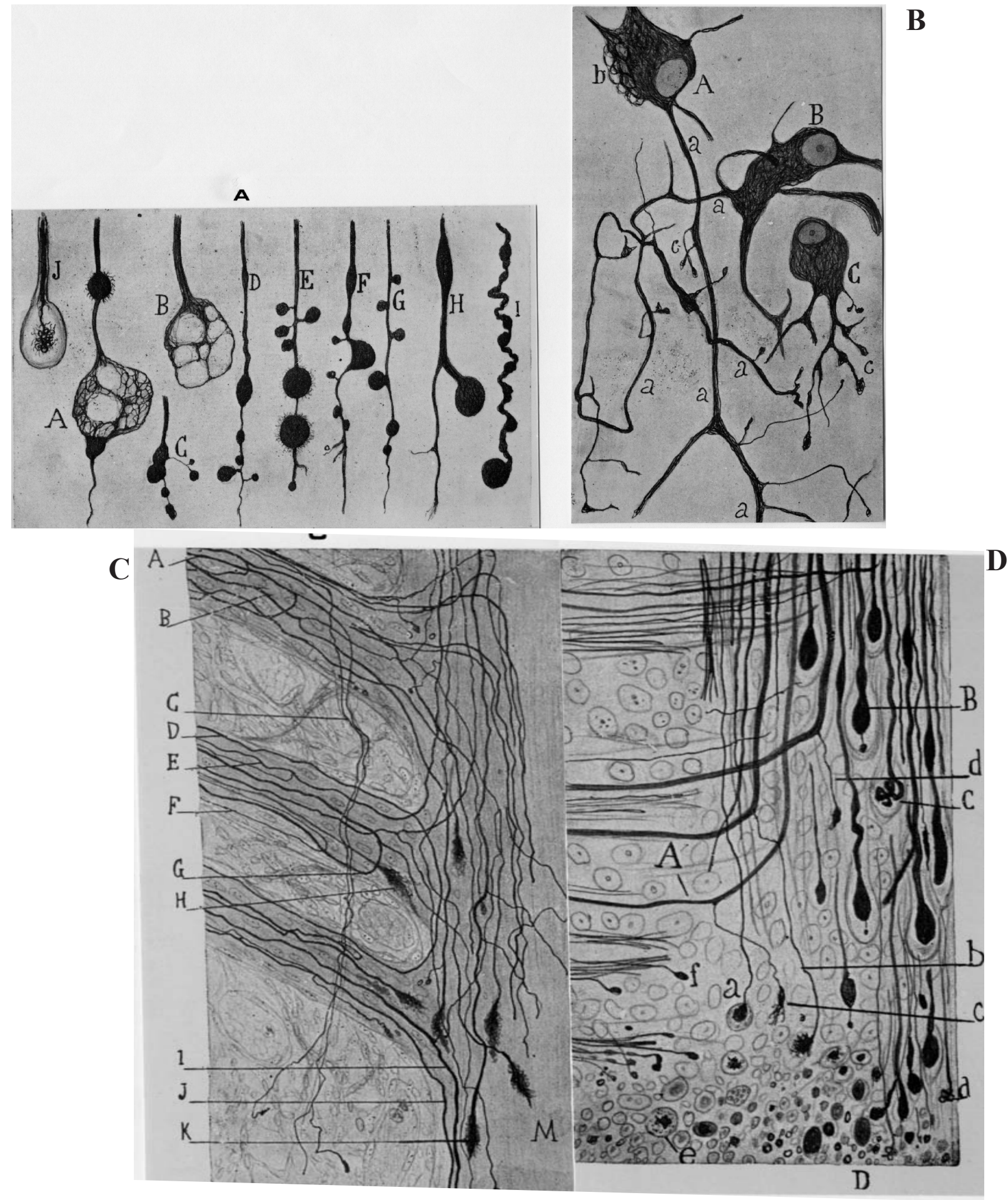

Figure 4. A. Various forms of alteration and regression of the retraction balls of the tubes of the white matter spinal cord. B. Large funicular cells from the base of the posterior horn of a traumatized spinal cord showing thickened axons in state of divisory turgidity. C. Piece of the posterior bundle and regenerated roots of a young dog whose terminal cord was lesioned in several places; penetrating fibres which abandon the cord, fibres which put out recurrent branches and arciform fibres which supply collaterals to the cord are seen. D. Piece of the central stump of the spinal wound of a young cat 3 days after the operation. $A=$ thickened collateral which will he transformed into terminal fibre. $a, b, c=$ longitudinal axons destined to disappear. $B$ and $C=$ clubs with appendices and final glomerulus, respectively. $e=$ free balls. 

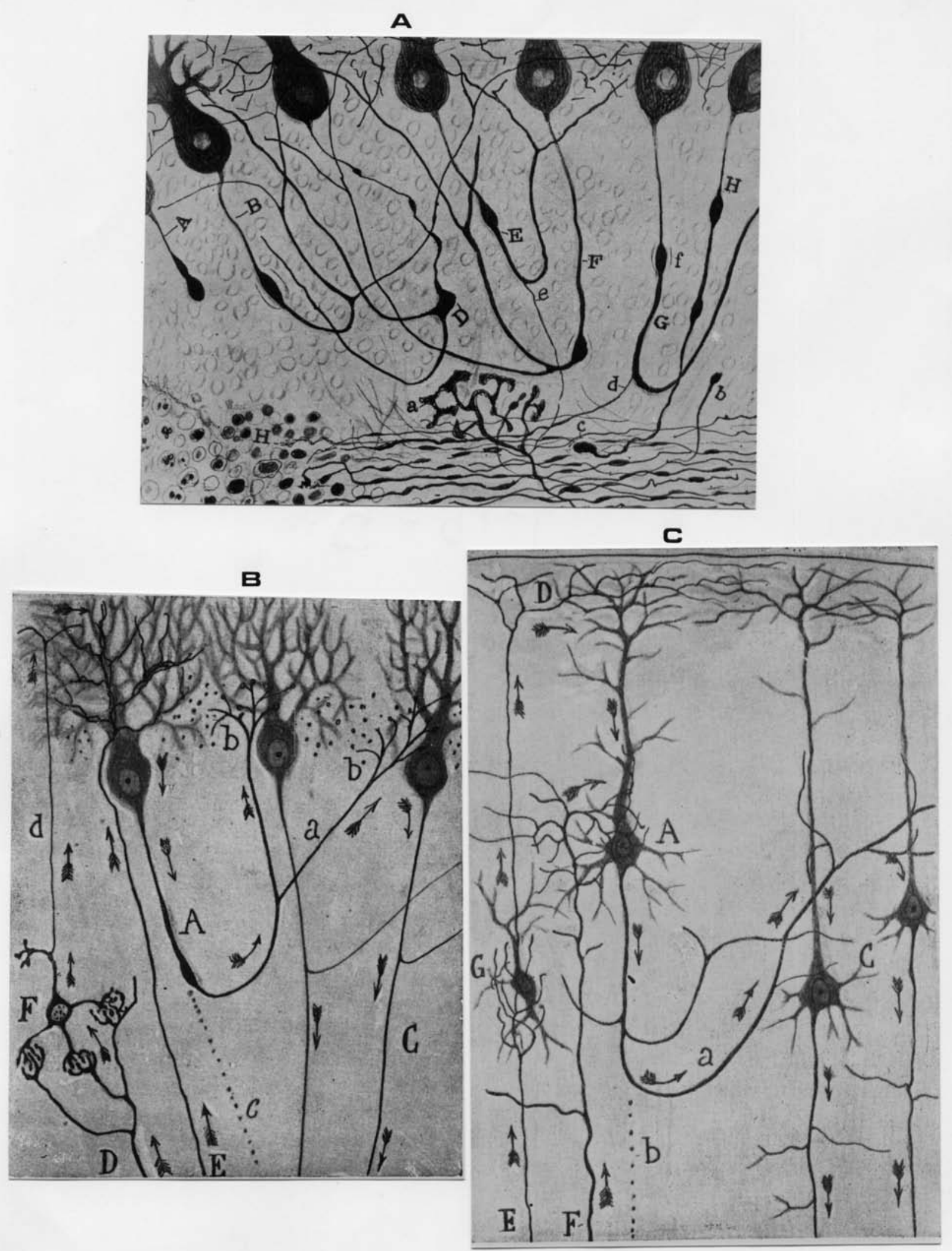


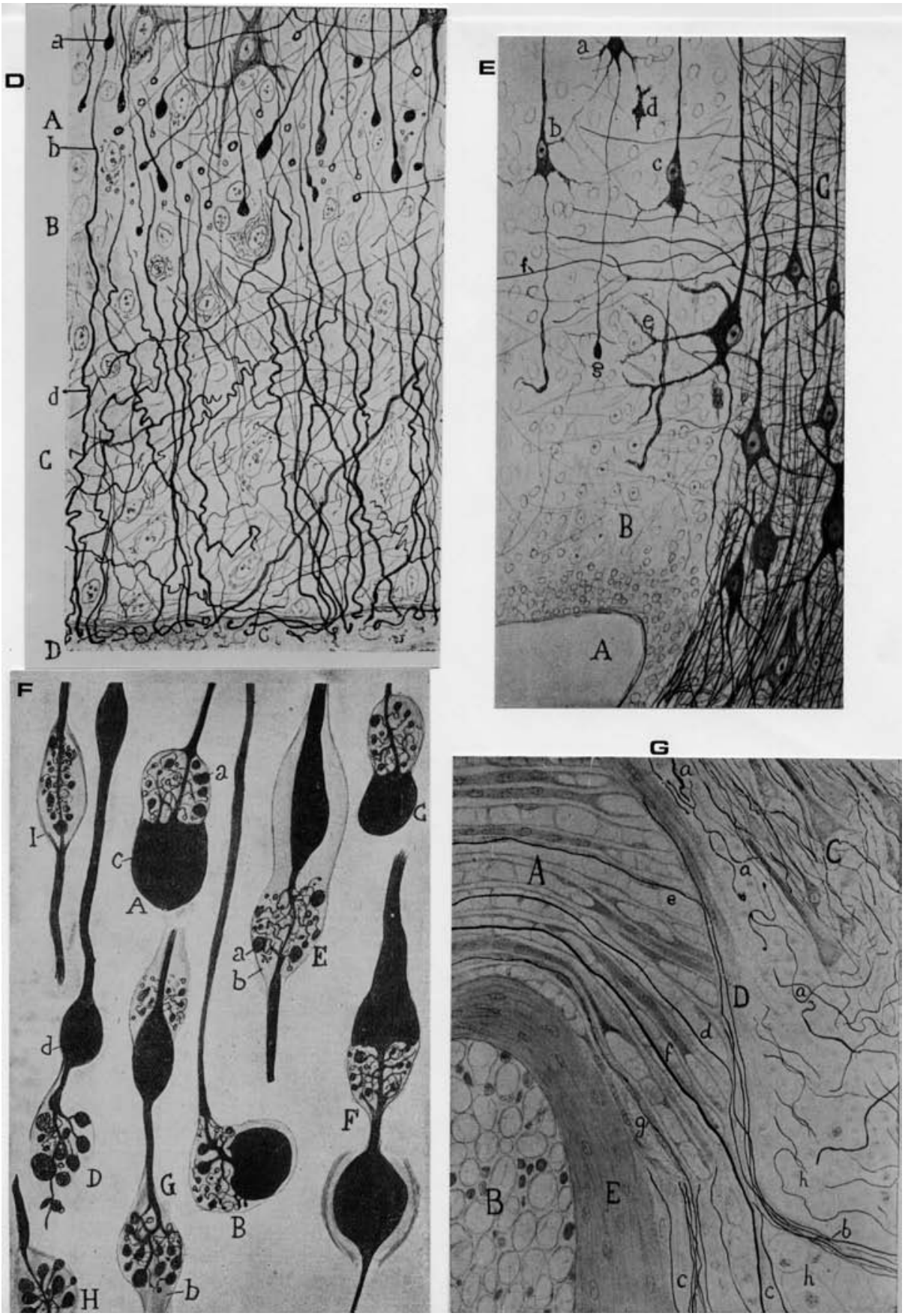

Figure 5. A. Section of the granular layer of the cerebellum of a young cat killed 3 days after a cerebellar wound was performed. $B, D$, $F$ are different types of arciform axons; following resorption of the extracollateral part of the axon the Purkinje cells become short axon neurons. $B$ and $C$. Schematic drawings showing the path of the currents in the short axon Purkinje and pyramidal neurons. $c, \quad b=$ positions previously occupied by the axons that have disappeared. D. Proximal edge of a transversal wound of the cerebrum of a young cat killed 24 hours after performing the operation. $A=$ living, reacting zone. $B=$ zone of corrosion and $C$ = zone of preserved fibres. E. Transverse wound of a circumvolution of a young cat killed 17 days after the operation; $C=$ healthy region of the cortex showing pyramidal cells with hypertrophic, recurrent nerve collaterals. F. Cephalopodic intraxonic neoformatios found in a cerebral wound of a young dog killed 56 hours after the operation. G. Living sciatic nerve graft in the cerebral cortex of an adult rabbit killed 14 days after the operation; fibres of the white matter are attracted by the graft.

a month or so after the operation, both the implanted piece and the newly formed fibres would eventually disappear.

In relation to the regenerative capacities of the nerve centres Cajal concluded: "All the above observations lead us to the conclusion that the central tracts are incapable of regeneration for the majority of regenerative acts described are aborted restoratory processes incapable of bringing about a definitive repair to the interrupted paths... It may also be inferred that this defective capacity for regeneration does not depend on essential, fatal and unchangeable con- ditions, but on the absence in the surroundings of catalytic agents able to provoke the nutrition of the cones and to direct them to the path that they must follow. These views are not held by the majority of neurologist... but we may recall that the fibres of the nerve centres, especially of the cord, form sprouts, more or less, when they are injured. Though on a lesser scale, this sprouting also occurs in the axons of the cerebrum, the optic nerve and the retina. It cannot be denied, therefore, that the central axons have the property of producing new fibres, and what has to be 
explained is why once the reconstructive movement is initiated the nerve sprouts lose their energy and suspend their growth".

At the end of the work Cajal stated: "It is for the science of the future to change, if possible, this harsh decree. Inspired with high ideals, it must work to impede or moderate the gradual decay of neurones, to overcome the almost invincible rigidity of their connections, and to establish normal nerve paths, when disease has severed centres that were intimately associated"

\section{Comment on Cajal's message to Spanish neuroscientists}

To the above vignette I would like to add a comment about the repercussion of Cajal's message on the Spanish scientific and academic medicine during the century elapsed since he was awarded with the Nobel Prize. Cajal's recommendations about research have universal validity, but some of them, charged with an honest sense of enthusiastic and constructive patriotism, were specifically drawn and addressed for young researchers and medical students in Spain, but unfortunately, the resonance of Cajal's voice into the Spanish academic world has remained below the expectations, and though things have started to change during the last two-three decades, there is very much left to be done.

I am aware that my comments may add very little to the well known significance of Cajal's figure, but as a professor of neurosurgery with responsibility in both graduate and postgraduate training, I feel compelled to remark once more the exemplar coherence between Cajal's life and the doctrine he proclaimed, which has been largely dismissed or ignored by his compatriots. I am certain that Cajal would have appreciated much more a minimal bit of adherence to his proposals of remedy for the ailments of Spanish science than the innumerable and redundant tributes we have been paying to him; in this respect it seems dishonest continuing to exalt the figure of Cajal while remaining indifferent to his philosophy. It is said that the quality of an university is not measured by the number of foreign professors invited to it, but by the number of their professors invited to visit other universities. Cajal, a solitary genius in a country astray from the industrial revolution, received invitations from many prestigious universities and outstanding neuroscientist in spite that he did not speak English or German and was able to employ a sadly imperfect French. In this respect it is enjoying reading Cajal's remembrances from his visit to England following the invitation by Sherrington to deliver the Croonian Lecture at the Royal Society ${ }^{4}$ and know about his thoughts and reflections on the differences in the industrial and social organization he observed in England as compared to his underdeveloped Spain.

The impression caused to Sherrington by the personality of his guest and his strong commitment to improve Spanish scientific landscape is also worth to read. Let us quote some lines about these impressions ${ }^{4}$ "The simplicity of Cajal's ways and ideas illustrates how singular a mixture he presented of old-time ways and ultramodern science. There was clearly an element of greatness in him. With peasantlike naiveté as to many of the ordinary conventions of life, there went a scientific enquirer who had transformed with novelty in the space of six short years, and singlehanded, the ancient study of the functional anatomy of the vertebrate nervous system. Is it too much to say of him that he is the greatest anatomist the nervous system has ever known? The subject had long been a favourite with some of the best investigators; previous to Cajal there were discoveries, discoveries which often left the physician more mystified than before, adding mystification without enlightenment. Cajal made it possible to recognize at a glance the direction taken by the nerve-current in the living cell, and in the nerve chain of nerve cells". "The consuming love for his country" also impressed Sherrington very much... "his patriotism, at once passionate and patient, was at the epoch in Spain submerged in a general flood of contemporary frustration, especially as to all that pertained to distinction and achievement in the realm of natural science. A devastating pessimism reigned in Spain in those years, paralyzing modern Spain's grasp of and competence in science. A comment of Cajal's own country men on his early publications ran to the effect: "Who is our Santiago to attempt to teach foreign savants?" But Cajal's own nature was far too strong for such despair. His faith in his country never faltered. His feeling was that if his country's powers had waned, it was for him and his contemporaries to give them renewal". "Often his reaction was regret at some defect he detected in Spain as contrasted with elsewhere... but the solicitude for his country's repute deserves explicit mention; it was perhaps the most powerful driving-force in the make-up of his whole scientific character. It lifted him altogether above all personal vanity". His science was first and foremost an offering to Spain".

Not just for the sake of justifying a personal desertion, but in an attempt to explain what happened to me and other young medical students, I will tell why I renounced at the very beginning of my career to cultivate the fascinating world of basic neurosciences. My perspective is that of a witness of the last forty years of the XX century, a period during which one could have reasonably expected Cajal envigorating ideas about research to flourish in our country. In the final analysis, the starting point for writing this vignette has been a feeling of personal gratitude to a man I never meet (Cajal), but from whom I had the privilege of receiving when I was medical student a "personal gift" charged with a significance I was unable to grasp at that time. Shakespeare coined the sentence "the little touch of 
Harry in the night" to describe the visit of Henry V to the soldiers of his outnumbered army going around the tents to encourage them in the mid of the night before a decisive battle. Many in our country received "the little touch of Cajal" but some, myself among them, did no open their minds to the essence of his message i.e, the admiration we should have for the natural world and the consequent devotion for science, the only mean or instrument we have to unveil their secrets.

In 1965 I was awarded with the "Santiago Ramón y Cajal" Prize created by Cajal himself to be given yearly at the Faculty of Medicine of the Complutense University in Madrid, where he was professor from 1892 to 1922, the year of his academic retirement. The creation of this prize is just another example of Cajal's generosity and willingness for reinforcing Spanish science. According to bylaws, the recipient of the award had to be a medical student selected by secret voting from their peers, and consisted of an amount of money taken from the endowment of his Nobel Prize, together with two books from his personal library. In this manner I had the immense, and at the same time undeserved honour of sharing a "little bite" of a Nobel Prize with a genius I much admire. My gladness was reinforced by the fact that the award was given in an unadorned but beautiful ceremony organized by the two most outstanding professors at our Faculty of Medicine at that time i.e., Fernando de Castro, professor of Histology, and direct pupil of Cajal, who should have shared the Nobel Prize of the year 1938 with the Belgian C. Heymans for their studies on the carotid sinus body, (Heymans himself proclaimed the mistake by the Nobel Prize Committee), and Antonio Gallego, professor of Physiology, who had received a second grade nutrition from Cajal through Lorente de Nó, another preeminent Cajal's pupil. I remember the brief speech addressed during prize giving, in which our professors exalted Cajal's commitment to impulse the Spanish science, with the aim of stimulating the audience mostly composed by young medical students. They strongly recommended us not only looking into Cajal's histological texts, but also reading his literary production aimed to orientate and reinforce the willingness and perseverance of medical researchers $^{9,11}$.

As other medical students at that time, I was sensible to the allure of the basic research, but the gloomy scientific landscape in our country dissuaded me from taking the advice of Antonio Gallego and his collaborator Alberto Oriol, to joining them as a physiologist. Instead, and perhaps unfortunately for me, I decided to leave the department of Physiology, where I have been working as undergraduate, and abandon the pathway of basic research in order to become a clinician, a position I considered less exciting scientifically speaking. A kind of persistent nostalgia for the laboratory, mixed perhaps with a feeling of blame, pushed me some years later, when I was a mature neurosurgeon, to revisite the laboratory in an attempt to make a modest contribution to the knowledge of the diseased nervous system, which was limited to the study of the reversible changes occurring in the innervation of cerebral arteries following experimental subarachnoid hemorrhage, a work performed for obtaining the Ph degree ${ }^{5,6}$.

Needless to say that Cajal ranked research activity or dedication above other "rutinary" activities, such as it is, at least in my opinion, the clinical work; however, he always emphasized that the combination of basic science and clinical work is imperative for the progression of medical knowledge (see the similarity of Sherrington opinions in this sense below). His statements in the respect are also worth to $\operatorname{read}^{7,9,11}$, much more in a country where both graduate and postgraduate curricula still remain ignorant of the necessity of training in research, a severe inconsistence detracting the overwhelming majority of our medical students from making a dive into the laboratory, and leading too many of them, endowed with bright minds, to become "mechanical and plain" caregivers. In this sense, it is rewarding to see how leading medical schools are introducing research education as a basic competence in undergraduate training, an innovation which could counteract the mental bias of trainees arriving to our hospitals to become specialists pursuing only clinical apprenticeship ${ }^{1,2}$. In any case, we would still have the pending step of introducing a period of training in research in the Residency programmes for reaching the standards currently prevalent in other developed countries.

Coming back to Cajal and Sherrington brotherhood respecting their views on the importance of research let us quote a comment published by Sherrington in his Address on Medical Science. "...in nurturing science, I would urge that a community cultivates more than mere utility... but to do this requires more than the devotion of individuals. It requires the intelligent cooperation of whole groups of individuals. Organized scientific inquiry becomes in advanced countries a conscious aim of the community as a community. That society may draw due to benefit from wells of natural knowledge, three kinds of workers have to stand side by side. First, the investigator, who pursuing truth, extends discovery, with little or no reference to practical ends. He constitutes the fountain-head of knowledge that is for distribution... after the investigator comes the teacher. To him it belongs to diffuse the knowledge won.. This honourable and difficult task receives its best reward in seeing the small spiritual beginnings of the pupil widen out into the spiritual beginnings of the master. Thirdly, there is the applier of natural knowledge. His part consists in making scientific knowledge directly serve practical needs. It is this work which, to the popular idea, often represents the whole science, or all of it that is commonly 
termed "useful". The practical results of this work are often astounding to those ignorant of the steps by which they have been reached. The greatest of these steps, however, is usually the first one, made in the laboratory of the investigator. These three co-workers are co-equal in the priesthood. Science and the applications of science are one growth, united together even as the fruit and the tree. The proper heartstone round which the community should group these laborers, labouring for a common end, is the University. There the sacred flame of learning is fed from many sides by many hands... for scientific medicine the student must, perforce, be thoroughly trained in his sciences before he can really grasp instructions or truly profit from his medical teaching... thus one of the aims of his instruction in empirical medicine is to teach him to observe for himself, so in his instruction on scientific medicine, one of its aims is to enable him to apply science for himself, as his life's work. This is the way to obtain enlightenment progress in professional practice. Thus the duties of a university do not begin and end with the disciplinary and didactic. Besides schools of instruction, they must be schools of thought. To be this latter, the laboratory must pursue research. Even for the welfare of the class-teaching this is essential. Instructive lectures may be given by men of ability, the whole of whose knowledge is second-hand, but it is doubtful whether the real life of science can be fully felt and communicated by one who has not himself learnt by direct inquiry from nature. Nothing so augments the teacher power of impressive and incisive teaching of a subject than to have faced problems in it himself as an original enquirer, and after rudiments have been once fairly acquired, there is for good students no training equal to that given by following even a small research under an experienced leader"... In reading these paragraphs one detects all the misunderstandings and origins of incompetence of the teaching of medicine in our country.

In summary, it is disturbing to realize that one century after Cajal's awarding with the Nobel Prize, most of our schools of medicine are still using obsolete curricula which, among other drawbacks, preclude the transmittal of his ideas to our medical students and young graduates. The Spanish scientific production has been so meagre for many years that one could take for granted the crude statement of our philosopher José Ortega y Gasset "The case of Cajal does not mean a pride for our country, but mostly a shame because it represents a rarity". We can not ignore the fatalism of history and how the explosion of the Spanish Civil War (1936-39) few years after Cajal's death in 1934, dismantled the emerging, but still fragile, scientific network. After the war some of Cajal,s pupils moved abroad for political reasons, others did so looking for a better grounded scientific world, and those remaining in Spain, like the above mentioned Fernando de Castro, had to deal with an almost total lack of funding for many years. This may explain in part why we have not had another Nobel Prize in the field of sciences (Severo Ochoa performed his work in USA). However, we must look ahead, and without forgetting those few neuroscientists who "carried the torch" up to the last two decades, welcome the flourishing army of young neuroscientists who are "irrigating the waste land" which surrounded Cajal during his entire productive life at the end of the XIX and the beginning of the XX centuries.

Apart from paying a humble personal tribute to Cajal, the other motivation for writing this historical vignette, was providing the readers of NEUROCIRUGIA, the Official Journal of the Spanish Neurosurgical Society, with a notice about this superb, and incredibly actual work I much enjoy, and the opportunity of contemplating some of his marvellous histological drawings which could go otherwise unobserved by many of them. We must remind that Cajal had not the possibility of taking photographs of their histological preparations; at that time histologists had to "paint" what they saw through the microscope, and in doing so there were artists, like Cajal, and non $\operatorname{artists}^{3}$. In 1899 Cajal stated "El buen dibujo, como la buena preparación microscópica, son pedazos de la realidad, documentos cientificos que conservan indefinidamente su valor y cuya revisión será siempre provechosa, cualesquiera que sean las interpretaciones a que hayan dado origen". (Good drawings, like good histological preparations, are pieces of the reality, scientific documents which keep their value for ever and whose review will be always fruitful, irrespective of the interpretations they have received or motivated).

\section{Agradecimientos}

I have to express my thanks to the former Director of the Cajal Institute in Madrid, Dr Joaquín del Río who gave me permission for using the Figures of the work "Degeneration and Regeneration of the Nervous System" in an article appearing in the proceedings of a meeting on "Recovery of Function of the Nervous System"

\section{References}

1. Ahn, J., Watt, Ch.D., Man, L.X., Greeley, A.S., Shea, J.A.: Educating future leaders of medical research: Analysis of student opinions and goals from the MD-Ph SAGE (Students, Attitudes, Goals, and Education) survey. Acad Med 2007; 82: 633-645.

2. Dannefer, E.F., Henson, L.C.: The portfolio approach to competency-based assessment at the Cleveland Clinic Lerner College of Medicine. Acad Med 2007; 82: 493-502.

3. De Felipe, J.: Cajal y sus dibujos: ciencia y arte. En, Arte y Neurología, Martin Araguz A (ed), Capitulo 18 Madrid, Editorial Saned; 2005 pp: 213-230. 
4. Eccles, J.C., Gibson, W.L.: Sherrington. His Life and Thought. Appendix 4\&5. Springer International. Berlin, 1979; pp: 201-209.

5. Lobato, R.D., Marín, J., Salaices, M. et al.: Effect of experimental subarachnoid hemorrhage on the adrenergic innervation of cerebral arteries. J Neurosurg 1980; 53: 477-479.

6. Lobato, R.D., Marín, J., Salaices, M. et al.: Cerebrovascular reactivity to noradrenaline and serotonin following experimental subarachnoid hemorrhage. J Neurosurg 1980; 53: 480-485.

7. Puerta, J.L.: Santiago Ramón y Cajal. 1906-2006. 100 años de un Premio Nobel. Barcelona; Grupo Ars XXI de Comunicación, 2006.

8. Ramón y Cajal, S.: Textura del sistema nervioso del hombre y de los vertebrados. Madrid; Imprenta y Librería
Moya, 1895.

9. Ramón y Cajal, S.: Recuerdos de mi vida. Historia de mi labor científica. Madrid; Imprenta y Librería Moya, 1917.

10. Ramón y Cajal, S.: Degeneration and Regeneration of the Nervous System. New York; Harper Press, 1969.

11. Ramón y Cajal, S.: Reglas y consejos sobre investigación científica. Los tónicos de la voluntad. Madrid; Colección Austral, Espasa Calpe, 1991.

Lobato, R.D.: Historical vignette of Cajal's work "Degeneration and regeneration of the nervous system"with a reflection of the author. Neurocirugía 2008; 19: 456-468.

Correspondencia postal: Ramiro D. Lobato. Servicio de Neurocirugía. Hospital "12 de Octubre". 28041 Madrid. 